\title{
Sistem Informasi E-Logistik Pada Siklus Proses Order BahanBaku
}

\author{
Diana Karlina W.P. ${ }^{1}$, Soetam Rizky Wicaksono ${ }^{2}$ \\ ${ }^{1,2}$ Program Studi Sistem Informasi, Universitas Ma Chung \\ Villa Puncak Tidar N-01, Malang 65151, Jawa Timur, Indonesia \\ Email :1320910005@student.machung.ac.id,2soetam.rizky@machung.ac.id
}

\begin{abstract}
Logistics activities have a big role in a company because it is the core of the company's activities. The utilization of e-logistics is essential as it will make the company more efficient. PT. XYZ is one of glass tube manufacturer with the production reaching up to 90,000 units of each day that causes the manufacturer takes a lot of components or raw materials, in which the raw materials required by the company are obtained from many suppliers. The process of procurement of supplies is carried out by the purchase order process. Information in the form of purchase order is submitted to the supplier, where the supplier is a partner of the companies involved in the flow of the materials. Logistic does not stop at booking, but includes the logistics flow of demand information of raw materials, as well as the process and stock storage of finished product and raw materials, and to the point where finished goods are shipped to the consumers. With the application of e-logistics, companies are expected to be able to collect and process the flow of information in the process of getting the raw materials and products in the production process, to create and maintain the cooperation between enterprises and suppliers in inventory control so that the process can be carried out efficiently.
\end{abstract}

Keywords: logistic, supply chain management, e-logistic

\begin{abstract}
Abstrak. Kegiatan logistik berperan besar di dalam sebuah perusahaan karena merupakan pusat operasional dari perusahaan. Pemanfaatan e-logistik sangat berguna, karena akan membuat perusahaan semakin efisien. Demikian pula halnya pada PT. XYZ salah satu perusahaan glasstube dengan produksi mencapai 90.000 satuan setiap harinya di mana pembuatan glasstube membutuhkan banyak komponen/ bahan baku, di mana bahan baku yang dibutuhkan oleh perusahaan didapatkan dari banyak supplier dan perusahaan pemasok lain. Informasi berupa order pembelian akan disampaikan kepada supplier, di mana supplier merupakan mitra perusahaan yang terlibat dalam aliran material. Tidak hanya berhenti pada proses pemesanan, namun logistik juga meliputi aliran informasi permintaan bahan baku, serta proses penyimpanan stok produk jadi maupun bahan baku, hingga barang jadi dikirimkan kepada konsumen. Dengan penerapan e-logistik diharapkan perusahaan mampu memproses aliran informasi dalam proses pemenuhan bahan baku dan produk dalam proses produksinya, membentuk kerjasama antara perusahaan dan supplier dalam pengendalian persediaan sehingga proses tersebut dapat dilakukan secara efisien.
\end{abstract}

Kata Kunci:logistik, supply chain management, e-logistik

\section{Pendahuluan}

Informasi adalah hal yang sangat krusial bagi proses bisnis suatu perusahaan (Laudon \& Laudon, 2008). Kebutuhan akan informasi ini terjadi seiring dengan meluasnya cakupan bisnis yang tidak mengenal jarak dan waktu. Dunia bisnis memerlukan ketersediaan informasi yang cepat dan tepat sehingga dapat memberikan suatu competitive advantage bagi perusahaan (Jogiyanto, 2009).Begitu pula dengan PT. XYZ,dengan produksi mencapai 
90.000 item per hari, pabrik ini merupakan sub-perusahaan yang khusus memasok glasstube sebagai salah satu raw material ke perusahaan lampu yang merupakan perusahaan utama.Salah satu aspek yang membutuhkan ketepatan informasi yaitu pengendalian persediaan, di mana pengendalian persediaan merupakan suatu aktifitas dari aliran material yang sangat penting bagi perusahaan ini. Bila terjadi kekurangan persediaan dalam gudang material yang dapat mengakibatkan terganggunya jalannya proses produksi, biaya pengadaan darurat dapat saja menjadi lebih mahal.

Sebaliknya, jika kelebihan persediaan bahan, akan menimbulkan penumpukan barang baik bahan baku maupun stok barang jadi di gudang perusahaan, sehingga menimbulkan membengkaknya biaya penyimpanan, serta berkurangnya nilai dari bahan baku, serta pengendapan modal perusahaan. Pengendalian barang akan menjamin ketersediaan bahan baku dan produk secara optimal, baik dalam jumlah maupun waktu.

Pembuatan glasstube membutuhkan banyak komponen/bahan baku, di mana bahan baku yang dibutuhkan oleh perusahaan didapatkan dari banyak supplier dan perusahaan pemasok lain. Proses pengadaan persediaan dilakukan dengan proses order atau pemesanan. Informasi berupa order pembelian akan disampaikan kepada supplier, di mana supplier merupakan mitra perusahaan yang terlibat dalam aliran material. Order berisi informasi mengenai nama barang, jumlah barang, waktu pengiriman, dan lain-lain. Sebelumnya proses pemesanan atau order dilakukan dengan transaksi manual atau pencatatan tangan sehingga kerap mengalami kendala di dalam proses transaksi harian. Padahal seharusnya terciptapengelolaan yang baik untuk menghindari kurangnya bahan baku untuk proses produksi, keterlambatan pengiriman bahan baku atau stok, maupun ketidakpastian produksi. Untuk mencapai hal tersebut, perusahaan harus menggunakan suatu strategi yang tepat, salah satunya ada penerapan e-Logistik.

\section{Sistem Informasi E-Logistik}

\subsection{Konsep Persediaan}

Persediaan dapat diartikan sebagai barang-barang yang disimpan untuk digunakan atau dijual pada masa atau periode yang akan datang. Persediaan terdiri dari bahan baku, persediaan bahan setengah jadi dan persediaan barang jadi (Rangkuti, 2007). Persediaan bahan-bahan baku dan bahan setengah jadi disimpan sebelum digunakan atau dimasukkan ke dalam proses produksi (industri manufaktur). Sedangkan persediaan barang yang dijual atau barang dagangan disimpan sebelum dijual atau dipasarkan.

\subsection{Sistem Pemesanan}

Menurut Astutie (2006), secara umum terdapat dua sistem pemesanan dalam sistem persediaan, yaitu: (1) Sistem Pemesanan Tunggal. Kebutuhan suatu barang untuk suatu periode waktu tertentu dipenuhi sekaligus dengan melakukan sekali pemesanan. Sifat seperti ini disebut sistem persediaan statis atau dikenal one shoot decision, yaitu suatu sistem persediaan pemesanannya hanya dilakukan satu kali untuk masa satu periode waktu tertentu. (2) Sistem Pemesanan Berulang (Periodik). Dalam sistem ini kebutuhan untuk satu periode waktu tertentu dipenuhi dengan melakukan pemesanan atau pembiayaan satu kali. Sifat seperti ini disebut dengan sistem persediaan dinamis atau dikenal dengan sebutan repetitive decision. Sistem pemesanan berulang (periodic) ini secara umum dibagi atas dua bagian, yaitu sistem dengan ukuran pemesanan tetap. Sistem ini sering disebut dengan istilah sistem pengendalian model Q atau Reorder Point Model yang kebijaksanaan ukuran pemesanan (order) yang tetap periode waktu pemesanan yang berbeda-beda. Prosedur utama dan sistem ini adalah kapan saja persediaan ada turun sampai mencapai titik pemesanan kembali (reorder point), maka sebuah pemesanan secara otomatis ditempatkan dengan jumlah atau ukuran tetap. Jadi, masalah pokok pengendalian persediaan dengan reorder point model ini adalah bagaimana menentukan titik pemesanan kembali (reorder point) dan menentukan jumlah atau ukuran pemesanan. Pada titik pemesanan kembali (reorder point) jumlah persediaan yang dimiliki sama dengan jumlah permintaan yang diharapkan selama waktu 
ancang-ancang (lead time) ditambah persediaan pengaman (safety stock) dan sistem pemesanan dengan periode waktu pemesanan tetap sistem ini sering disebut dengan istilah sistem pengendalian persediaan model $\mathrm{P}$ atau periodic review model $(\mathrm{R}, \mathrm{T})$ yang didasarkan kebijaksanaan periode waktu pemesanan yang tetap tetapi dengan ukuran pemesanan yang bervariasi. Prosedur utamanya adalah setiap periode waktu tertentu (jangka waktu tertentu) pemesanan ditempatkan sejumlah ukuran tertentu yang bervariasi, yang dihitung dengan mengurangi secara langsung jumlah persediaan yang ada dari jumlah persediaan sebelumnya yang telah ditentukan atau dengan perkataan lain sejumlah pesanan akan ditempatkan untuk membawa posisi persediaan atau jumlah persediaan sampai posisi $\mathrm{R}$ yang telah ditentukan. Jadi, masalah pokok pengendalian persediaan dengan sistem ini adalah bagaimana menentukan periode waktu pemesanan dan berapa jumlah persediaan yang diinginkan pada awal siklus (R). (3) Waktu Ancang-Ancang (Lead Time). Yaitu periode waktu yang dibutuhkan mulai dari pemesanan ditempatkan hingga barang diterima di gudang. Waktu ancang-ancang ini bisa bersifat tetap (deterministic) atau mungkin juga berubah-ubah sesuai dengan pola distribusi kemungkinan tertentu (probabilistic).

\subsection{Metode EOQ (Economic Order Quantity)}

Menurut Pujawan (2005), salah satu metode manajemen persediaan yang paling terkenal adalah metode Economic Order Quantity atau bisa disebut dengan EOQ. Metode ini menganggap bahwa biaya penyimpanan material dan biaya pemesanan material merupakan biaya-biaya yang relevan di dalam pembuatan keputusan mengenai persediaan. Oleh karena itu, biaya-biaya tersebut harus diminimumkan.

Jika "S" adalah biaya pemesanan, biaya pemesanan yang dimaksud adalah biaya yang selalu keluar setiap kali pemesanan dan tidak tergantung pada ukuran atau volume pesanan dan jika "h" adalah biaya penyimpanan per unit per periode, di mana biaya penyimpanan adalah biaya yang terjadi akibat perusahaan menyimpan barang tertentu dalam satu periode tertentu. Dimisalkan "D" sebagai material yang diperlukan dalam suatu periode perencanaan dan "Q" adalah unit material pada setiap pemesanan. Bila biaya pemesanan yang timbul adalah $\mathrm{S}$, maka EOQ dapat dijelaskan dengan rumus pada persamaan 1 (Ristono, 2009).

$$
Q(E O Q)=\overline{\frac{2 D S}{h}}
$$

Keterangan:

$D$ : material yang diperlukan dalam suatu periode perencanaan

$Q:$ unit material yang dipesan

$S:$ biaya pemesanan

$h$ : biaya penyimpanan per unit per periode

\subsection{Logistik}

Menurut Siagian (2005), logistik merupakan bagian dari proses rantai suplai yang berfungsi merencanakan, melaksanakan, mengontrol secara efektif, efisien proses pengadaan, pengelolaan barang, pelayanan dan informasi mulai dari titik awal (point of origin) hingga titik konsumsi (point of consumption) dengan tujuan memenuhi kebutuhan konsumen.

Logistik adalah pemindahan sumber daya ke dalam organisasi (masuk) dan produkproduk dari organisasi kepada para pelanggannya (keluar) (Bateman \& Snell, 2007). Seperti rantai pasokan, logistik sebuah perusahaan seringkali merupakan unsur yang sangat penting dari responsivitas dan keunggulan kompetitifnya. Dari definisi tersebut dapat disimpulkan bahwa kegiatan manajemen logistik berkaitan dengan: (1) Proses perencanaan bahan/material, (2) Proses pengadaan bahan/material, (3) Proses pengelolaan dan 
penyimpanan, (4) Proses pemindahan bahan/material dari gudang ke pabrik. Keempat kegiatan ini sebagai titik awal (point of origin), sedangkan kegiatan kelima dan keenam sebagai titik konsumsi (point of consumption). (5) Proses pengelolaan dan penyimpanan barang jadi (finished good), (6) Proses distribusi barang jadi dari gudang pabrik ke konsumen.

\section{Implementasi Sistem}

\subsection{Proses Produksi}

Manajer produksi pada awalnya akan memasukkan data dan jumlah bahan baku yang dibutuhkan untuk membuat satu jenis produk tertentu. Form Bill of Material (gambar 1) digunakan manajer produksi untuk menuliskan bahan baku apa saja dan berapa jumlah bahan baku untuk memproduksi 1 unit barang. Kemudian, staff produksi memasukkan data Target Produksi Harian. Data yang dimasukkan adalah pada tanggal berapa produksi akan dilaksanakan, dan berapa banyak produk yang harus dihasilkan oleh perusahaan. Proses entri data dapat dilihat pada gambar 1 di saat proses bahan baku utama diinputkan pertama kali.
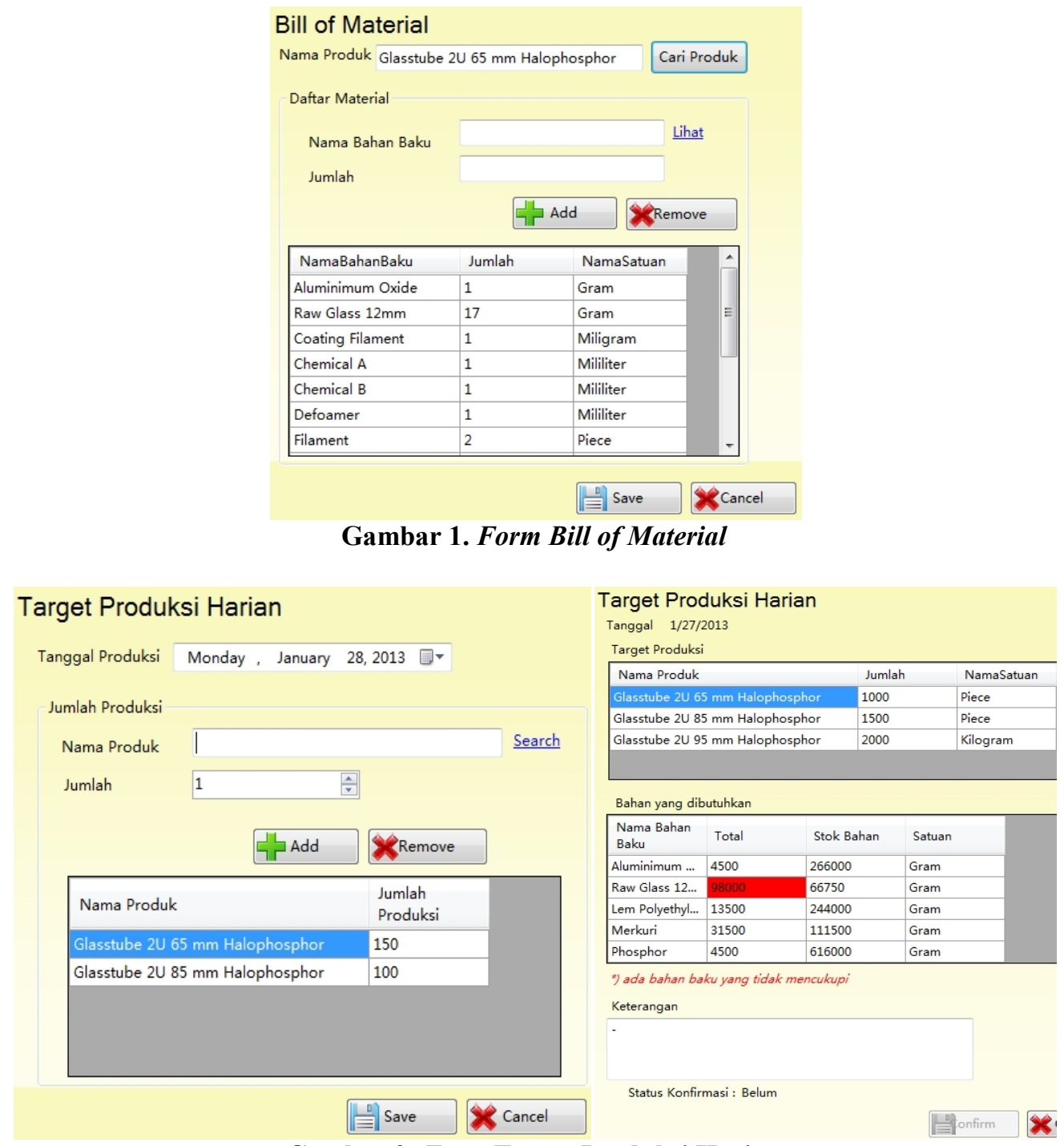

Gambar 2. Form Target Produksi Harian

Data target produksi ini nantinya harus dikonfirmasi oleh manajer produksi, sebagai tanda bahwa manajer produksi telah menyetujui data target produksi tersebut dengan form input yang terbagi menjadi dua jenis seperti yang tertera di gambar 2. Jika data target 
produksi harian telah disetujui oleh manajer produksi, pada hari pelaksanaan produksi staff material warehouse akan melakukan perhitungan bahan baku yang diperlukan oleh divisi produksi untuk memproduksi barang.
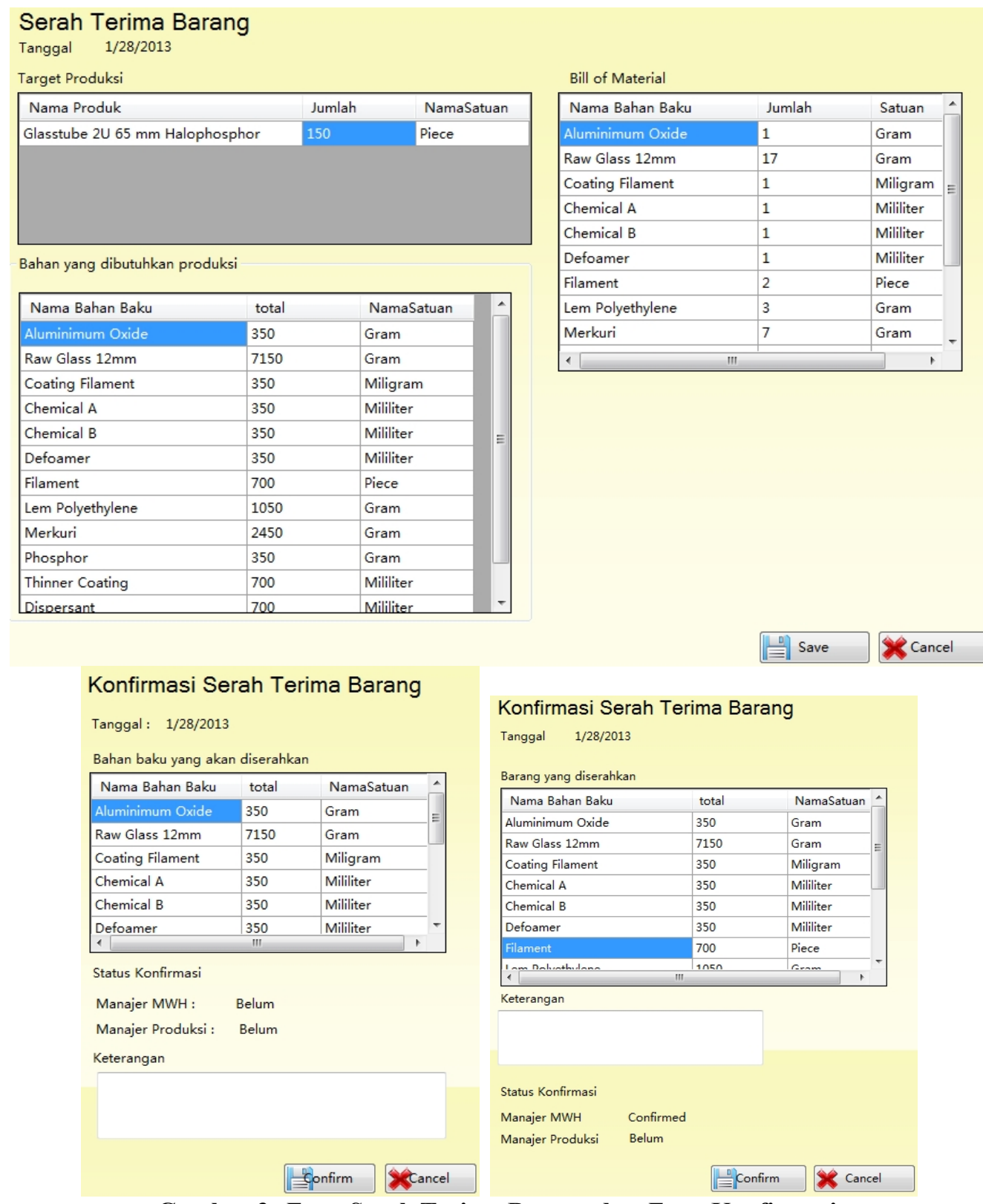

Gambar 3. Form Serah Terima Barang dan Form Konfirmasi

Dokumen serah terima barang ini harus diperiksa/dikonfirmasi oleh manajer gudang sebagai tanda bahwa barang dengan jumlah yang tertera akan keluar dari gudang. Penyerahan bahan baku juga dikonfirmasi oleh pihak produksi sebagai tanda bahwa bahan yang dikirimkan telah sesuai dan proses produksi dapat segera dilakukan. Setelah divisi produksi melakukan proses produksi, hasil produksi dihitung oleh staffquality control, hasil produksi akan dicatat pada dokumen laporan produksi harian, berapa banyak produk baik yang dihasilkan maupun produk yang tidak layak (afalan). Proses untuk penyerahan dokumen hingga saat konfirmasi dari pihak staf quality control dapat ditelaah di gambar 3. Data ini akan dikonfirmasi terlebih dahulu oleh manajer quality control sebagai pihak yang mengetahui jalannya proses penghitungan. Tahap yang paling akhir dari proses ini adalah 
proses konfirmasi dari manajer produksi, sebagai tanda bahwa dokumen tersebut telah sesuai. Proses konfirmasi di dalam sistem dapat dilihat pada gambar 4.

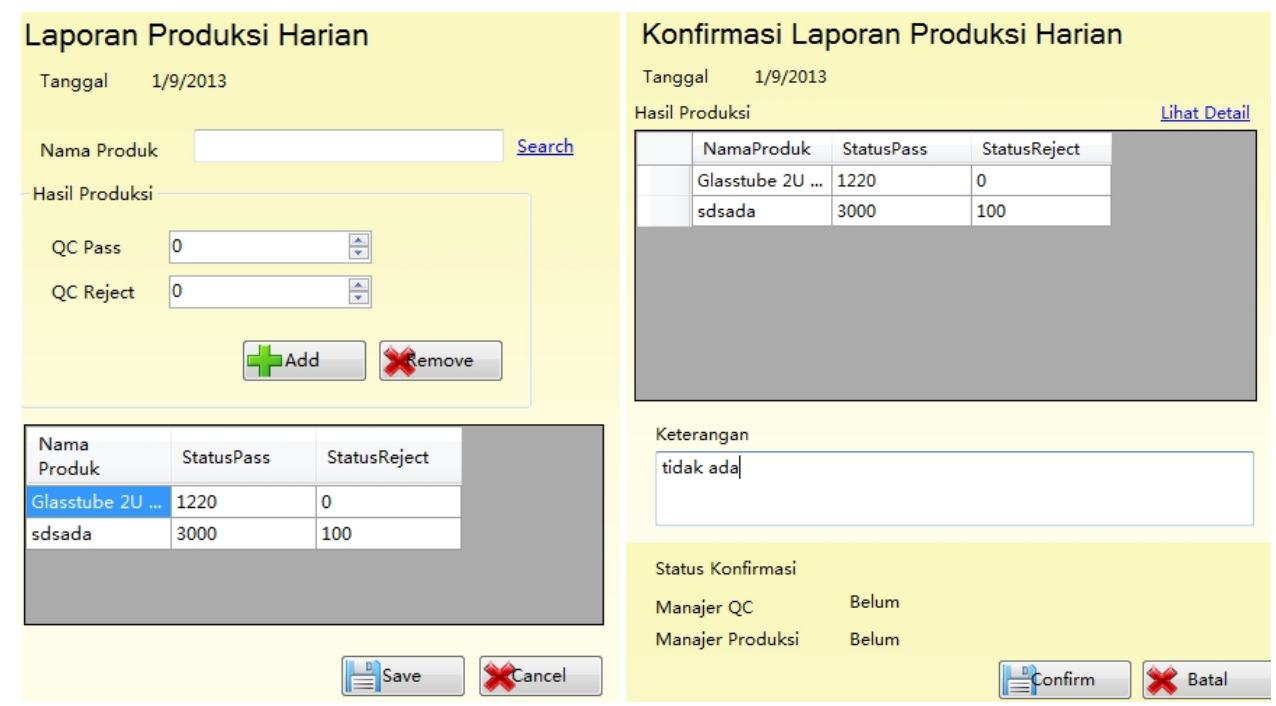

Gambar 4. Form Laporan Produksi Harian dan Form Konfirmasi

\subsection{Pengiriman Barang Jadi}

Hasil produksi perusahaan akan menghasilkan barang jadi yang akan dikirimkan kepada konsumen staff Material Warehouse akan mengecek produk yang tersedia di dalam gudang dan menentukan jumlah barang yang akan dikirimkan kepada konsumen. Proses pengiriman hingga cetak laporan yang akan digunakan sebagai surat jalan dapat dilihat pada gambar 5 dan gambar 6 .

Pada form pengiriman, staff material warehouse dapat memasukkan data kendaraan yang digunakan, pengemudi, berapa jumlah kemasan barang, dan berapa jumlah fisik barang, serta berapa jumlah afalan yang akan dikirimkan kepada perusahaan utama. Data pengiriman barang yang telah dikonfirmasi ini nantinya menghasilkan surat jalan yang akan diterima oleh konsumen.

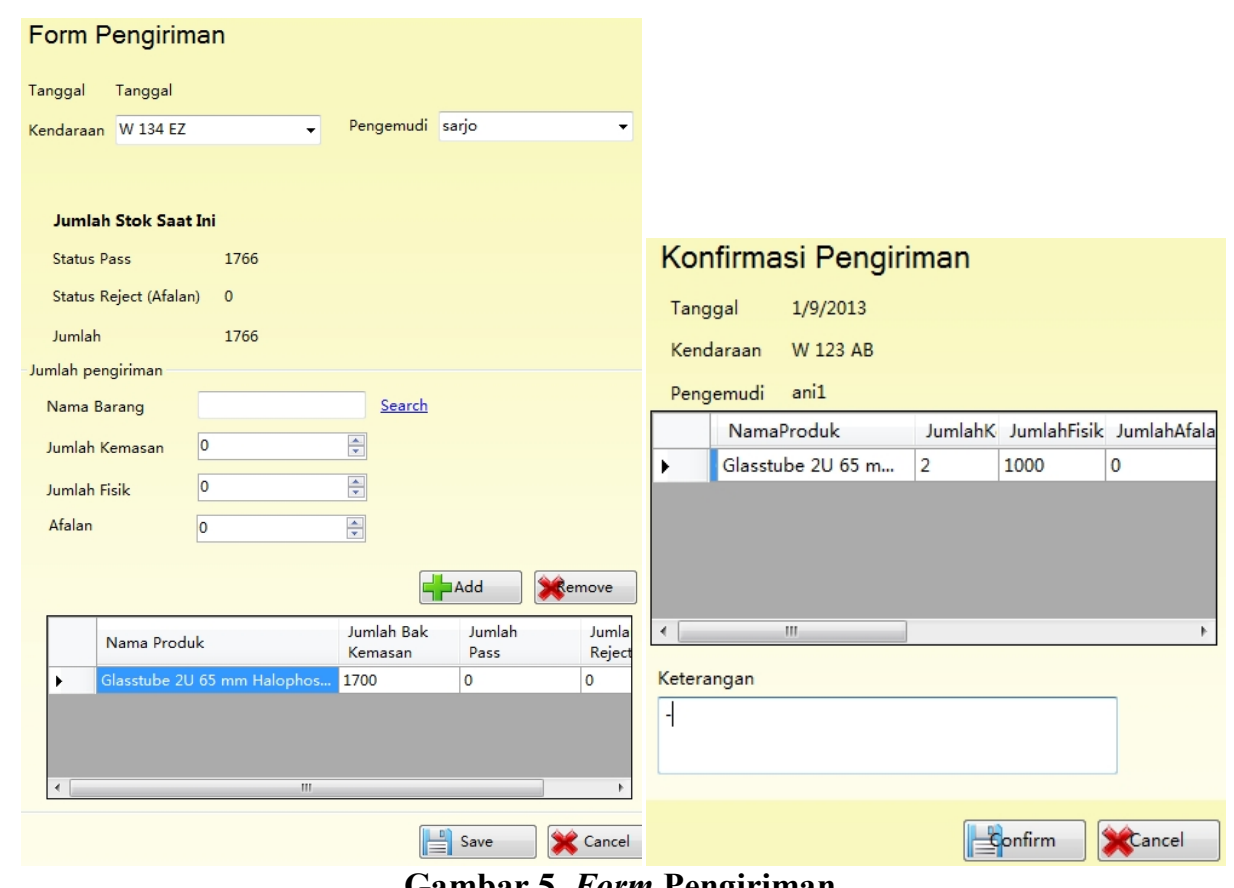

Gambar 5. Form Pengiriman 


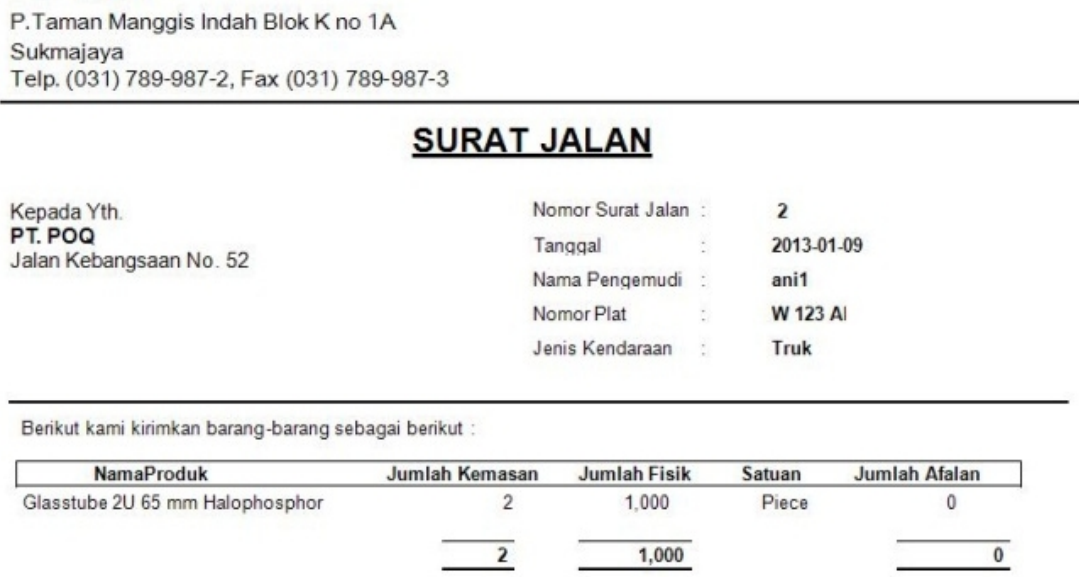

Gambar 6. Surat Jalan

\subsection{Proses Permintaan Bahan Baku}

Untuk menentukan minimum stok yang ada di gudang, manajer produksi wajib menentukan AKM (Acuan Kebutuhan Material), yaitu berapa banyak suatu material dibutuhkan dalam jangka waktu produksi tertentu. Perusahaan menggunakan metode EOQ untuk perhitungan berapa banyak bahan baku yang perlu dipesan dan minimum stok bahan yang ada di gudang. Saat penyimpanan data Acuan Kebutuhan Material inilah sistem akan menghitung jumlah minimum stock ideal bagi perusahaan (gambar 7). Saat suatu bahan telah mencapai minimum stok staffmaterial warehouse akan memasukkan data permintaan bahan dengan jumlah yang disesuaikan dengan kapasitas gudang dan kebutuhan produksi.

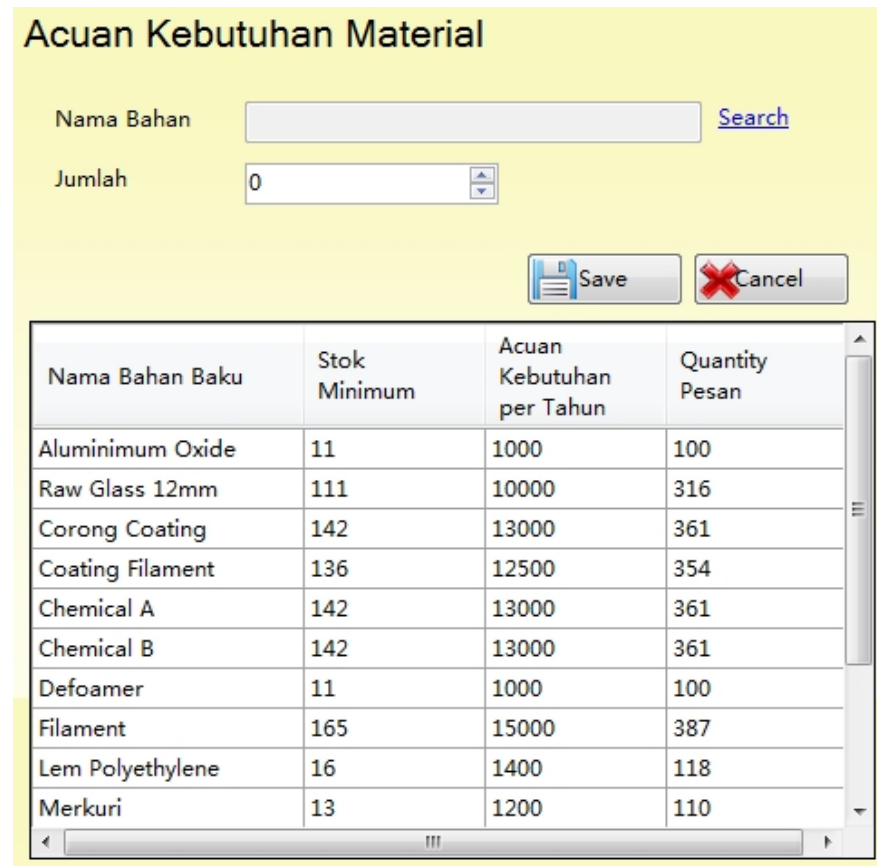

Gambar 7. Form Acuan Kebutuhan Material

Data Purchase Requisition dikonfirmasi oleh manajer material warehouse sebagai pihak yang mengetahui. Data pemintaan bahan baku yang telah diterima oleh pihak purchasing akan diolah oleh staff purchasing dalam pemilihan supplier mana yang akan menyuplai bahan baku. Pengisian data tersebut disebut juga sebagai requisition and confirmation dengan model form seperti yang tertera di gambar 8 . 

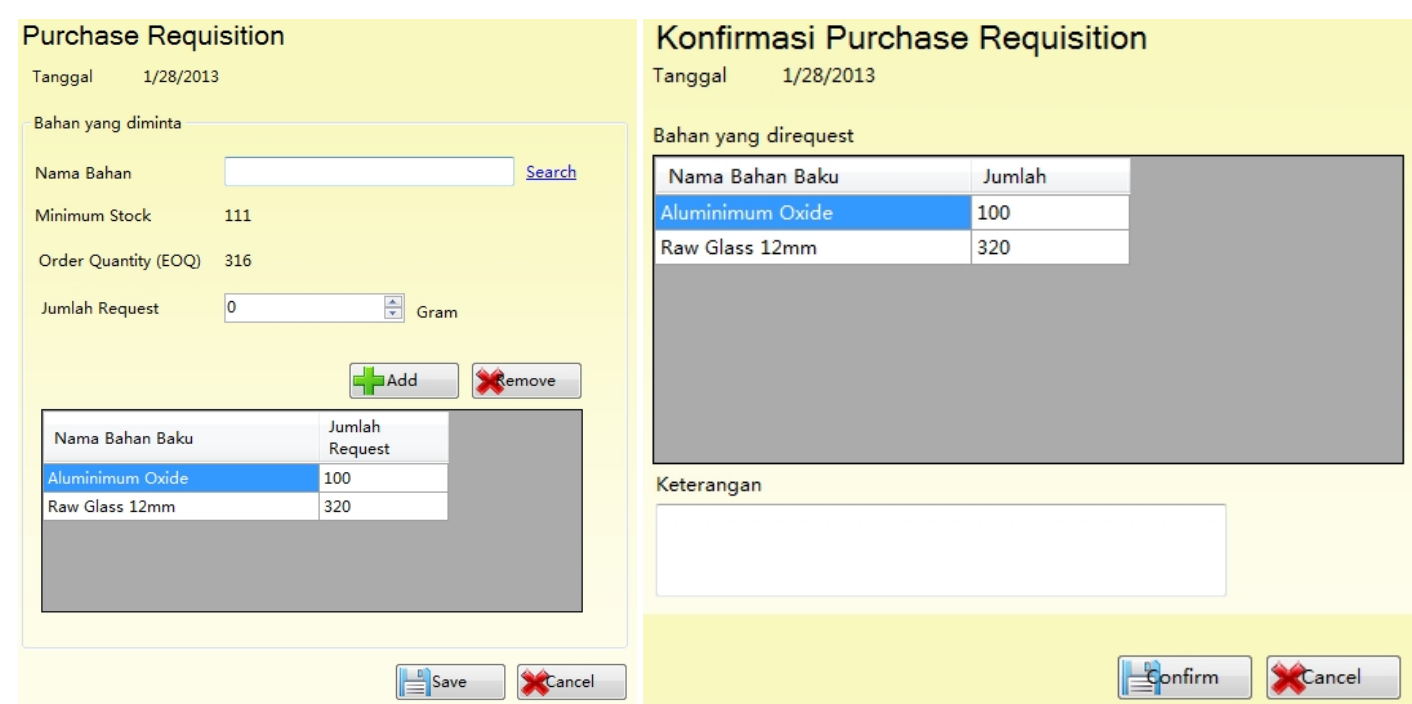

Gambar 8. FormPurchase Requisition dan Konfirmasi

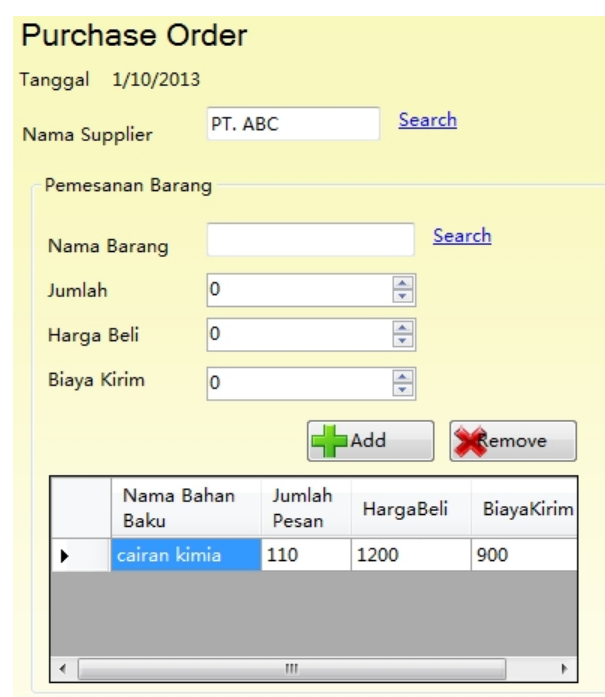

\section{Konfirmasi Purchase Order}

Tanggal $1 / 28 / 2013$

Nama Supplier PT. ABC

Bahan yang dipesan

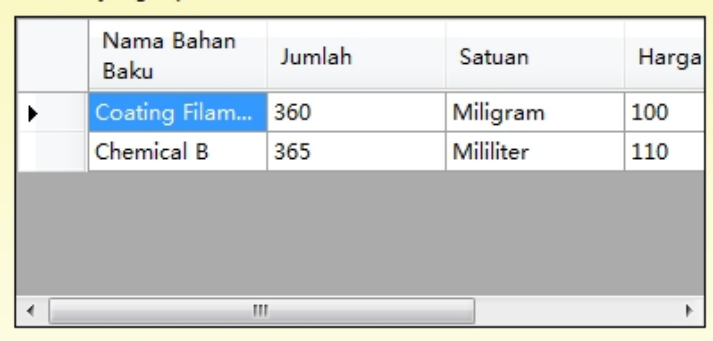

Keterangan
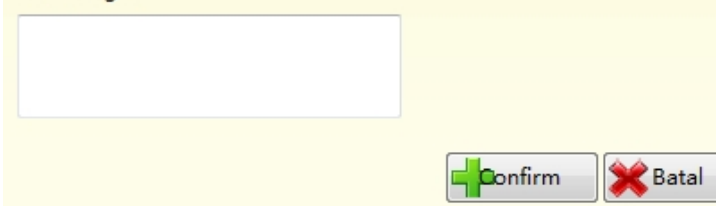

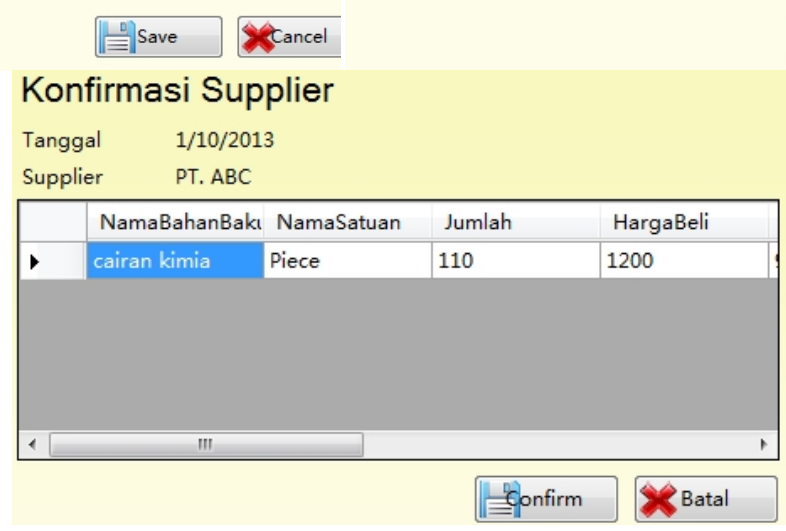

Gambar 9. Form Purchase Order dan Konfirmasi

StaffPurchasing akan memasukkan data bahan yang akan dibeli dari supplier, berapa jumlah serta harga beli serta harga kirimnya. Data purchase order pembelian ini akan disetujui terlebih dahulu oleh manajer purchasing. Konfirmasi terakhir untuk data purchase order ini dilakukan oleh manajer finance untuk mengetahui harga beli dari produk yang dipesan. Supplier akan menghubungi pihak purchasing dapat atau tidaknya pihak supplier 
dalam memenuhi pesanan dari perusahaan. Segera setelah PO diterima, pihak supplier akan memenuhi pesanan perusahaan. Proses ini dapat dilihat pada gambar 9 .

\subsection{Proses Penerimaan Bahan}

Pesanan yang telah data akan diterima oleh pihak material warehouse, dan akan dicatat di dalam dokumen Incoming Inspection Report oleh staff material warehouse. Data ini akan dikonfirmasi oleh manajer material warehouse sebagai pihak yang mengetahui. Data Incoming Inspection Report yang telah dikonfirmasi oleh manajer material warehouse bernama Bukti Menerima Barang dan dapat dilihat pada gambar 10.

Untuk kasus tertentu jika terjadi kekurangan atau kerusakan barang, staff purchasing akan membuat dokumen bernama Corrective Preventive Action Report yang bertujuan untuk menentukan tindakan yang dipilih berkenaan bahan kurang atau cacat yang dikirimkan oleh supplier. Penentuan ini dilakukan pada saat barang telah selesai dicek dan dimasukkan pada form yang tertera di gambar 11.

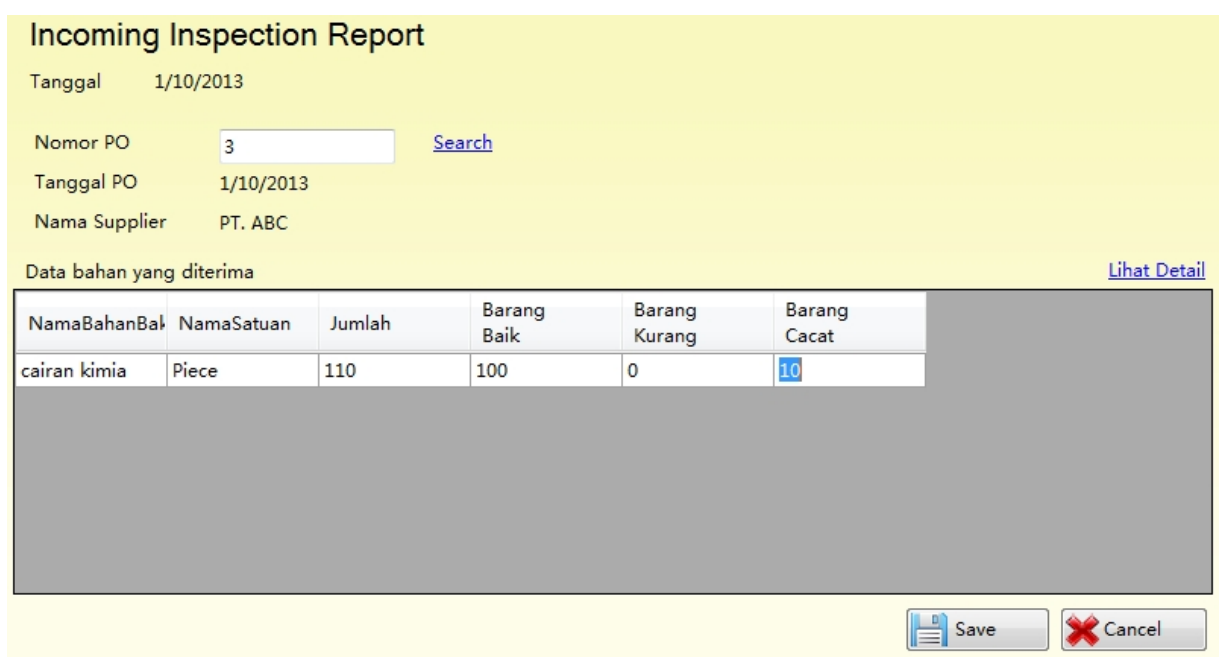

Gambar 10. Form Incoming Inspection Report

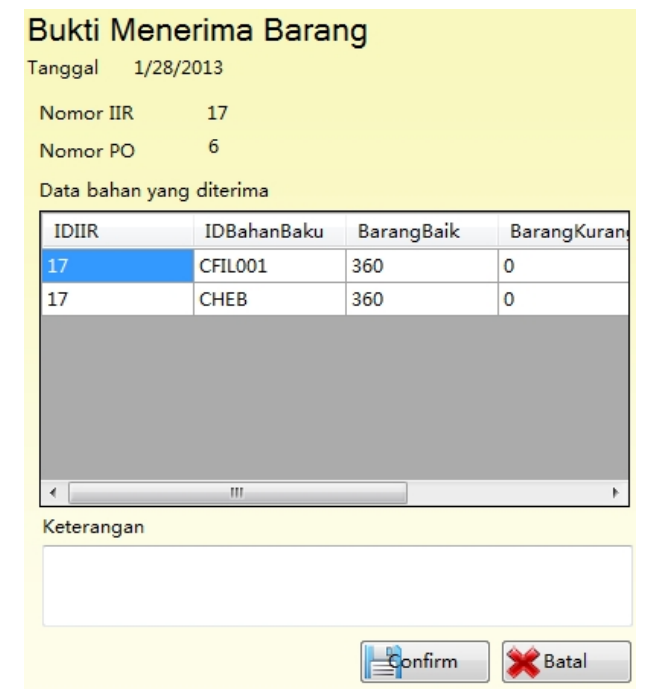

Gambar 11. Form Bukti Menerima Barang

Dokumen ini akan dikonfirmasi oleh manajer purchasing. Jika tindakan merupakan tindakan retur kepada supplier, maka staff purchasing akan membuat dokumen purchase order dengan status retur. Pada saat proses terakhir ini dilakukan, maka berarti proses pembelian dapat dikatakan selesai (form koreksi dapat dilihat pada gambar 12). 


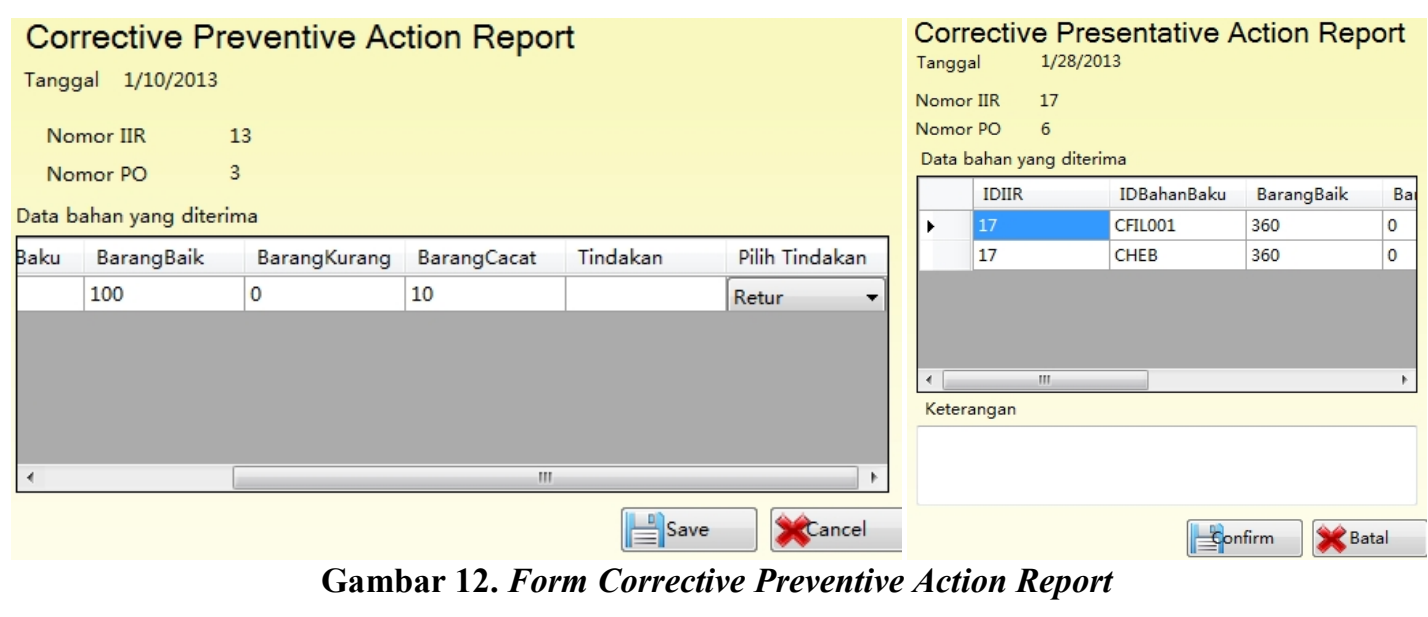

\subsection{Uji Coba SMS}

Berikut adalah hasil uji coba terhadap fitur SMS gateway.Fitur ini digunakan pada saat pengiriman data Purchase Order kepada Supplier terpilih. Isi dari SMS tersebut yaitu: tanggal Purchase Order, nama barang dan jumlah barang yang dipesan, serta panduan pesan konfirmasi yang harus dilakukan oleh supplier sehubungan dengan purchase order yang telah diterima, tabel 1 menunjukkan contoh SMS PO yang dikirimkan.

Tabel 1. Tabel Uji Coba Pengiriman SMS Multi Provider

\begin{tabular}{lcl}
\hline \multicolumn{2}{c}{ Pengirim } \\
\hline Penerima & \multicolumn{1}{c}{ XL } & \multicolumn{1}{c}{ Simpati } \\
\hline XL & SUKSES 11.33 detik & SUKSES18.00 detik \\
\hline Simpati & SUKSES 09.98 detik & SUKSES 14.13 detik \\
\hline Axis & SUKSES 13.73 detik & SUKSES 15.06 detik \\
\hline $\operatorname{Im} 3$ & SUKSES 16.97 detik & SUKES 10.05 detik \\
\hline
\end{tabular}

\section{Kesimpulan}

Dengan adanya sistem informasi logistik, setiap divisi dalam perusahaan dapat mengetahui dan saling berbagi informasi mengenai aliran bahan di dalam perusahaan, baik berupa bahan mentah maupun produk jadi. Sistem informasi logistik serta perhitungan stok minimum, perusahaan dapat mengetahui berapa besar bahan baku yang dibutuhkan setiap periode produksi.

\section{Referensi}

Astutie, H. K., 2006. Analisis Tentang Pengendalian Persediaan dalam Perusahaan. Jurnal Ekonomi dan Manajemen, pp. Vol. 7 (1) : 41-45.

Bateman, T. S. \& Snell, S. A., 2007. MANAJEMEN : Kepemimpinan dan Kolaborasi dalam Dunia yang Kompetitif Buku 1. 7 ed. Jakarta: Penerbit Salemba Empat.

Jogiyanto, H., 2009. Sistem Teknologi Informasi. Yogyakarta: Penerbit ANDI.

Laudon, K. \& Laudon, J. P., 2008. Sistem Informasi Manajemen Mengelola Perusahaan Digital Buku 1. Jakarta: Penerbit Salemba Empat.

Pujawan, I. N., 2005. Supply Chain Management. Surabaya: Penerbit Guna Widya.

Rangkuti, F., 2007. Manajemen Persediaan Aplikasi di Bidang Bisnis. Jakarta: PT Raja Grafindo Persada.

Ristono, A., 2009. Manajemen Persediaan. Yogyakarta: Graha Ilmu.

Siagian, Y. M., 2005. Aplikasi Supply Chain Manajemen dalam Dunia Bisnis. Jakarta: PT. Grasindo. 